Perspective

\title{
An Historical Perspective on Psychiatric Genetics, the International Society of Psychiatric Genetics and the Role of Elliot Gershon
}

\author{
Lynn E. DeLisi ${ }^{1,2}$ \\ 1 Department of Psychiatry, Harvard Medical School, Boston, MA 02215, USA; \\ Email: Lynn_DeLisi@HMS.Harvard.edu \\ 2 Cambridge Hospital, Cambridge Health Alliance, Cambridge, MA 20139, USA
}

\begin{abstract}
Psychiatric Genetics is a relatively new field that was defined by groups of researchers interested in the familial aggregation of psychiatric disorders, and spurred on by the escalating new field of molecular genetics beginning in the 1980s. This manuscript contributes to a special issue honoring the career of Elliot S. Gershon, a true pioneer and critical thinker, who contributed substantially to the development of this field and also its stimulating meetings that brought colleagues together to discuss the latest research findings. It details the role Dr. Gershon played in establishing the precursor of the International Society of Psychiatric Genetics (ISPG) and how he remains in a leadership role on its Board of Directors and was honored with one of the ISPG Lifetime Achievement Awards.
\end{abstract}

KEYWORDS: gsychiatric genetics; ISPG; WCPG

The field of Genetics was likely born about the time that Mendel reported his experiments on traits of pea plants and how they were transmitted through generations of new seedlings [1,2]. The words "gene" and "Genetics", originating from the Greek, meaning "of noble birth" or "to give birth", came into scientific use when William Bateson used the term "genetics" to describe inherited variations [3], referring to Mendel's Open Access

Received: 07 September 2019

Accepted: 08 October 2019

Published: 16 October 2019

Copyright (c) 2019 by the author(s). Licensee Hapres, London, United Kingdom. This is an open access article distributed under the terms and conditions of Creative Commons Attribution 4.0 International License. work, and when Wilhelm Ludvig Johanssen [4], a few years later in 1909, coined the word "gene" to refer to a unit of Mendelian inheritance (https://www.genome.gov/25520244/online-education-kit-1909-the-wordgene-coined). Despite Emil Kraepelin and some of his colleagues having described clusters of psychotic illness within families, it was not until large family studies in the 20th century were collected and their illness patterns observed that psychiatric disorders were thought to have any familial vulnerability or relationship to genes. These prompted further twin concordance studies and then adoption studies that ultimately solidified the notion that genetic factors led to psychiatric illness. Psychiatric Genetics was not a field, nor a term used in psychiatry, until much later. 
Some of the earliest refinement of family study methodology was published by Elliot Gershon with colleagues in the 1970s and early 1980s (e.g., [5,6]). The landmark discovery of the Huntington's gene in 1982 [7] then led to early investigations in the Gershon laboratory to using similar methodology to finding a gene for bipolar disorder and schizophrenia (e.g., [8]).

I first met Elliot Gershon, the head of the National Institutes of Mental Health (NIMH) Neurogenetics Laboratory, sometime in 1978. I was at that time a post-doctoral fellow in Richard Wyatt's Adult Psychopharmacology NIMH Branch at the Saint Elizabeths Hospital in Washington, DC. It was Dr. Wyatt's idea that my first project should involve a collaboration with Dr. Gershon to examine a popular biological marker for schizophrenia, Platelet Monoamine Oxidase Acitivity (pMAO), and determine whether the activity was inherited and related to the inheritance of schizophrenia. The study design was to be using families with multiple ill members, comparing affected and non affected members. However, when, in preliminary studies, we determined that pMAO activity was lowered by antipsychotic medication [9], the family studies were never pursued. About the same time, I attempted to engage Dr. Gershon in studies of the "Genain" Quadruplets, 4 monozygotic women, all of whom developed chronic schizophrenia. Again, this collaboration failed because Dr. Gershon was adamant that any studies of these women were essentially an "N" of "one" and thus would not advance the field further. Nevertheless, my interest in genetics persisted and I joined the Gershon laboratory in 1984 to pursue the new field of molecular genetics in families with schizophrenia [10-12], initially beginning by confirming the extent of the genetic effect in a carefully controlled new family study [13].

On Friday, October 23, 1992 Theodore Reich, Professor of Psychiatry at Washington University in St Louis invited a handful of colleagues ( $T$ Crow, JFW Deakin, L DeLisi, R Elston, D Kirch, J Nurnberger, R Todd) to his department to discuss plans for a congress of psychiatric genetics to be held in the USA sometime in 1993. A few previous events led up to and initiated this landmark St. Louis meeting, one of which was a workshop organized by E Gershon, R Cloninger, P Propping and L DeLisi with funding and support contributed by Professor Hans Hippius from Bonn, Germany (Figure 1). It was an invited 2-day conference, held in Berlin in 1986, for approximately 30 international senior researchers focused on the genetics of mainly schizophrenia. Its aim was to discuss the unanswered questions and to form hypotheses to pursue in future genetic collaborations. The success of this workshop led to two of its attendees, Timothy Crow and Peter McGuffin from the UK, establishing The World Congress of Psychiatric Genetics (WCPG) as a meeting of the Biological Psychiatry Division of the British Royal College of Psychiatrists. The first 2 WCPGs sponsored by this division of the Royal College were held in Cambridge in 1989 (Figure 2) and London in 2001, and attracted 
approximately 200 researchers. It was at the last one that there was talk among some of the American attendees about bringing the WCPG to the USA. Cold Spring Harbor was investigated by Dr. Crow as an obvious site, but was decided to be too small and then abandoned to the preferences of Dr. Reich who thought that having the first USA congress as a satellite of the American Society of Human Genetics annual meeting in New Orleans in 1993 seemed the best prospect for success. There was much discussion at that seminal October 1992 meeting about the further future of world congresses and how important it would be not to have one person surface spontaneously to decide it was time to organize a meeting. Chaos, competition, and unnecessary political dealings would ensue. Thus, in order to ensure some stability and transparency to the process for future WCPGs, it was decided to form a non-profit society of interested researchers and thus to have an advisory Board, program committee and officers that would rotate over the years according to a set of by-laws. Thus, while the other attendees at the St Louis meeting took roles in the planning of a 1st USA New Orleans meeting, I volunteered to look into the feasibility of forming a society, and proceeding with the necessary pieces. The first step would be to see if in fact there was interest among colleagues to belong to such a society. A flyer was developed announcing the society and stating for a nominal fee of 10 dollars one could become a member. The mail quickly began accumulating huge numbers of envelopes (and money) from people wishing to become members and it was only then that the administrative complexities of beginning a society and its pieces began to become apparent, i.e., incorporation, application for legal charitable status in the USA, opening a bank account in the name of a "society". These happened within a short time with the aid of a former psychiatric researcher in my laboratory, G Shields, who then lived in Nevada. Thus, the ISPG was incorporated with Dr. Shields as the "resident" administrator, in Nevada for a very small fee and over time gained 501c USA non-profit status. By the time of the New Orleans congress and the first in person Board meeting, the International Society of Psychiatric Genetics (ISPG) had a founding Board of Directors $(N=8)$, By-Laws, approximately 300 members, and 2 life-time achievement prize winners who were honored (Seymour Kety and George Winokur)(Figure 3) with an original sculpture of DNA designed and completed by NY artist, Charles Reina. The rest is "history" that many colleagues listed in Tables 1-4 have been part of at different times. The notable events during the past 27 years have been, (1) an established relationship by contract with the journal Neuropsychiatric Genetics and a lesser, but still important relationship with the journal, Psychiatric Genetics in the 1990's. These two important journals were the first specialty journals in the field, having begun about the same time independently late 1980s early 1990s even before the society was officially born. (2) Grant support from the USA National Institutes of Drug Abuse and Alcohol Abuse, led by J Nurnberger and L 
DeLisi from 1999 on for several years. These funds were able to provide a travel awardee program for students and young investigators. (3) A travel awardee rapporteur program was established in 2007 whereby coordinated reporting on sessions by travel awardees resulted in a later publication (e.g., [14-16]) documenting the notable events of the congresses. (4) the establishment of Chromosome Workshops to integrate data being produced during the era of early first-generation genomewide linkage studies, (5) An Educational Day was established in 2005 to take place 1 day prior to each WCPG for reviews of different aspects of the field for new investigators beginning work in psychiatric genetics, as well as the informed public and media. (6) A notable field trip took place to Hadamar Psychiatric Hospital in 1998 during the Bonn WCPG to educate genetic researchers about the use of eugenics to form policies about psychiatric patients during the Nazi era and the resulting extermination of thousands of psychiatric patients, bringing to the forefront important lessons from history about the potential misuse of psychiatric information. (7) Other ethical issues were discussed and policies formulated, one dealing with the use of family members for ascertainment of information in genetic studies and the question of who were the "research subjects" requiring informed consent. Another discussion was on addressing the need for a collective society supported statement to the public about the use of genetic testing in psychiatry. (8) Collaborative efforts to enlarge numbers of subjects in large genomewide studies were discussed at in person meetings during WCPG (most notably in a symposium at the end of the WCPG 2005 in Boston) and thus it can be said that the WCPG and ISPG facilitated the world-wide development of ideas for sharing of data and collections. These included both the NIMH Genetics Initiative, which then led to the Psychiatric Genomics Consortium in the years from 2005 to 2008.

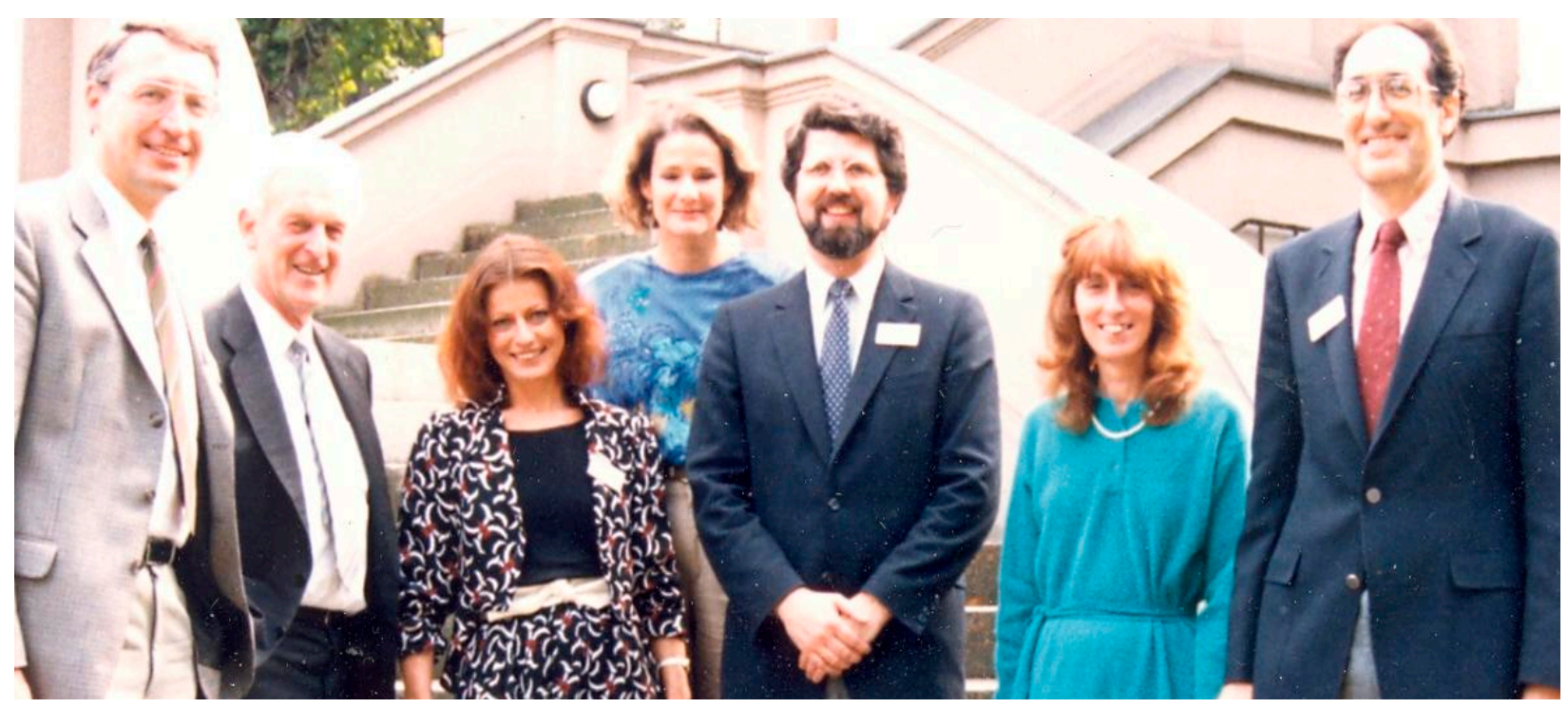

Figure 1. Berlin, October 1986: Left to right: P Propping, H Hippius, B Bondi, unknown assistant to H Hippius, R Cloninger, L DeLisi, E Gershon. 


\section{FIRST WORLD CONGRESS \\ ON \\ PSYCHIATRIC GENETICS \\ A Conference organised by the Biological Psychiatry Group of \\ the Royal College of Psychiatrists under the auspices of the \\ World Federation of Societies of Biological Psychiatry \\ CHURCHILL COLLEGE, CAMBRIDGE, ENGLAND \\ 3 rd - 5th AUGUST 1989}

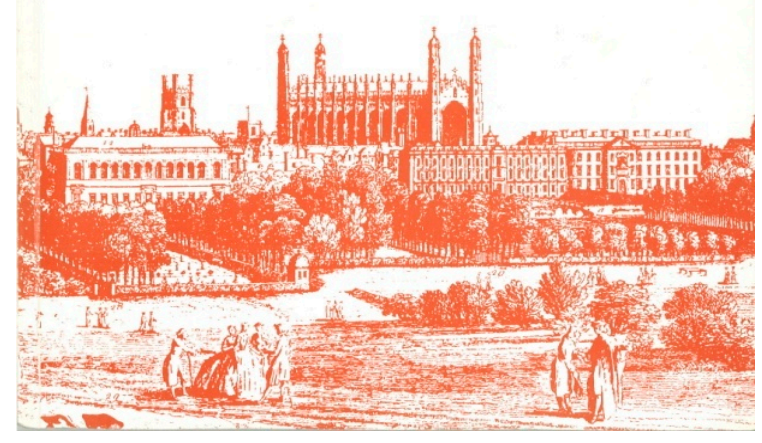

Figure 2. Preliminary meetings held by TJ Crow and P McGuffin in 1989 and 1991 in Cambridge and London as part of The Royal College of Psychiatrists, Biological Psychiatry group. The Cambridge program.

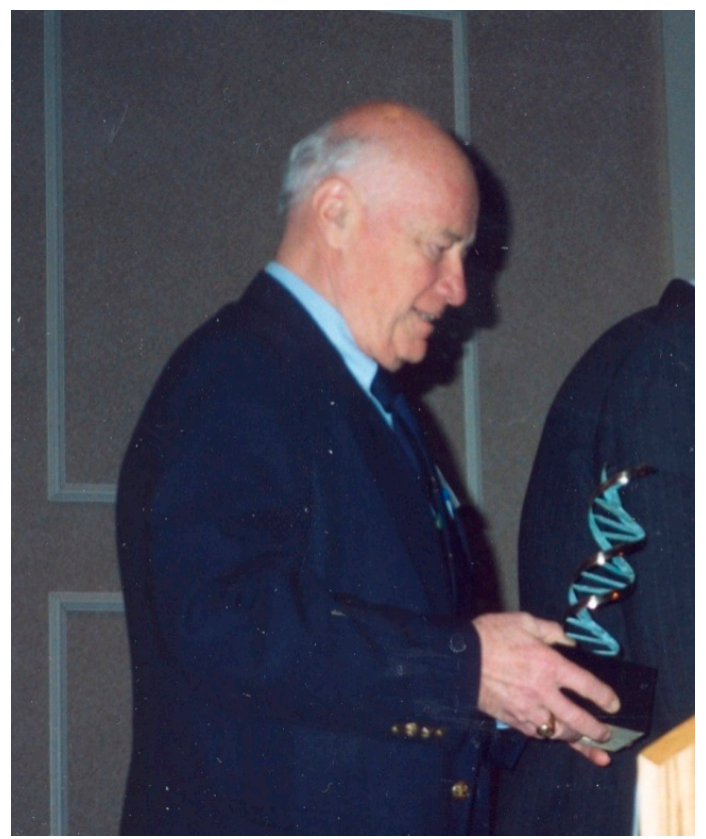

(A) George Winokur

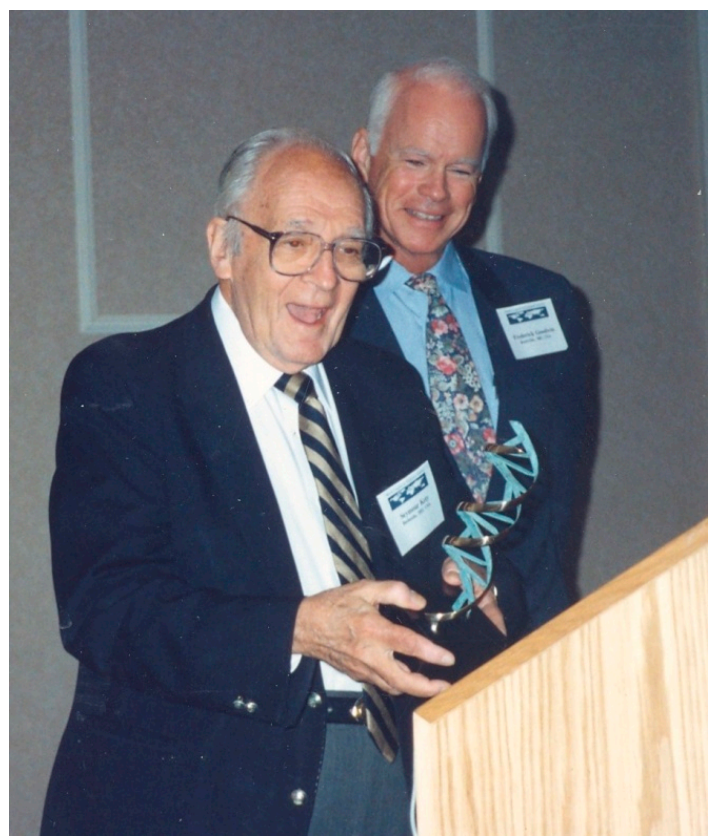

(B) Seymour Kety with Fred Goodwin looking on

Figure 3. The First meeting of the incorporated International Society of Psychiatric Genetics in New Orleans, October, 1993. Both George Winokur and Seymour Kety were honored with the first society lifetime achievement awards for their landmark family (George Winokur) and adoption (Seymour Kety) studies of schizophrenia that led to the search for genetic causes of schizophrenia and all major mental illness. 
Thus, while the main mission of the society is to educate and facilitate advancement in research on psychiatric genetics, important political and ethical issues involving the use of genetics were not ignored and will continue to be discussed. In 2011 the society executive office moved from my university academic office, to a professional society management company, Parthenon Management Company, under the auspices of the American College of Neuropsychopharmacology and Dr. Ronnie Wilkins as company president. This enabled the society to continue to expand its professional status in coming years and have a consistent organization to its annual congresses. These were and still are exciting times for the uncovering of genetic mechanisms for disease and the ISPG has been at the forefront in facilitating progress toward the understanding of the genetics of mental illness and facilitating large collaborative efforts to meet and do so.

The following tables summarize the notable researchers who contributed to the leadership of the ISPG in its first 27 years and to the field of Psychiatric Genetics in general. Table 1 lists the officers and terms of office. Table 2 lists the names of Board members and their estimated terms of office. Table 3 lists the many international venues and the chairs of each that were sponsored by the ISPG and the named World Congress of Psychiatric Genetics (WCPG). Until 1996, these were biennial meetings and then quickly became annual congresses beginning in 1997 in Santa Fe. Table 4 lists the many awards and their recipients given by the ISPG to recognize achievements in psychiatric genetics. The first award was founded by $\mathrm{T}$ Reich and myself to honor two of the most eminent leaders in the field of psychiatric genetics at that time in 1992, Seymour Kety (for his adoption studies in Denmark) and George Winokur (for the Iowa 500 family cohort).

Table 1. Officers from 1992 to Present.

\begin{tabular}{|l|}
\hline PRESIDENT \\
\hline Theodore Reich $*$ : 1992-1996 \\
\hline Peter McGuffin: $1997-2000$ \\
\hline Michael Owen: 2001-2005 \\
\hline Ming Tsuang: 2006-2010 \\
\hline Nicholas Craddock: 2011-2012 \\
\hline Francis McMahon: 2013-2015 \\
\hline Thomas Schulze: 2016-present \\
\hline
\end{tabular}


Table 1. Cont.

\begin{tabular}{|l|}
\hline VICE PRESIDENT \\
\hline Timothy Crow: 1992-1996 \\
\hline Michael Owen: $1997-2000$ \\
\hline Christine van Broeckhoven: 2001-2005 \\
\hline Stephen Faraone: 2006-2010 \\
\hline Francis McMahon: 2011-2012 \\
\hline Marcella Rietschel: 2013-2015 \\
\hline Jordan Smoller: 2016-present \\
\hline SECRETARY \\
\hline Lynn DeLisi: $1992-2012$ \\
\hline Thomas Schulze: 2013-2015 \\
\hline Elizabeth Binder: 2016-present \\
\hline TREASURER \\
\hline Richard Todd *: 2005-2008 \\
\hline John Rice: 2008-2015 \\
\hline James Potash: 2016-present \\
* deceased.
\end{tabular}

* deceased.

Table 2. Board members and estimated terms (some are based on best memory and may be inaccurate).

\begin{tabular}{|c|}
\hline Kenji Abe: 1995-2002 \\
\hline Laura Almasy: 2008-2014 \\
\hline Jehannine Austin: 2018-present \\
\hline Nicholas Barden: 2002-2004 \\
\hline Samuel Barondes: 1994-2011 \\
\hline Kate Berg: 1994-1998 \\
\hline Sarah Bergen: 2014-present \\
\hline Elisabeth Binder: 2014-present \\
\hline Margit Burmeister: 2008-present \\
\hline Nicholas Craddock: 2000-2011 \\
\hline Timothy Crow ${ }^{\dagger}:$ 1992-2011 \\
\hline Lynn DeLisi †: 1992-2013 \\
\hline William Deakin ${ }^{\star}$ : 1992-2000 \\
\hline Robert Elston ${ }^{\dagger, *}:$ 1992-1999 \\
\hline Steve Faraone: 2003-2012 \\
\hline Susan Folstein: 2000-2004 \\
\hline Barbara Franke: 2018-present \\
\hline Elliott Gershon: 2008-present \\
\hline Michael Gill: 2002-2016 \\
\hline Irv Gottesman *: 1995-2010 \\
\hline John Kelsoe: 2012-2018 \\
\hline Ken Kendler: 1995-2000 \\
\hline James Kennedy: 2008-present \\
\hline
\end{tabular}


Table 2. Cont.

\begin{tabular}{|c|}
\hline Darryl Kirch ${ }^{\dagger}:$ 1992-1997 \\
\hline Douglas Levinson: $2000-2016$ \\
\hline Jacque Mallet: 1995-2010 \\
\hline Peter McGuffin: 1994-2008 \\
\hline Francis McMahon: 2004-2016 \\
\hline Sarah Medland: 2018-present \\
\hline Benjamin Neale: 2018-present \\
\hline Markus Nöthen: 2000-2018 \\
\hline John Nurnberger ${ }^{\dagger}:$ 1992-2018 \\
\hline Michael Owen: 1995-2013 \\
\hline Lena Peltonen *: 1992-2009 \\
\hline James Potash: 2014-present \\
\hline Peter Propping *: 1994-2010 \\
\hline Henriette Raventos: 2018-present \\
\hline Ted Reich ${ }^{\dagger, *}:$ 1992-2003 \\
\hline John Rice: 1999-2016 \\
\hline Marcella Rietschel: 2010-2016 \\
\hline Dan Rujescu: 2014-present \\
\hline Thomas Schulze: 2008-present \\
\hline Jonathan Sebat: 2010-present \\
\hline Jordan Smoller: 2010-present \\
\hline Patrick Sullivan: 2016-2018 \\
\hline Richard Todd ${ }^{\dagger, *}:$ 1992-2008 \\
\hline Ming Tsuang: 1995-2013 \\
\hline Christine van Broekhoven: 1995-2009 \\
\hline Kenneth Warren: 1994-2000 \\
\hline Naomi Wray: 2016-present \\
\hline Pamela Sklar *: 2016-2017 \\
\hline Maria del Zompo: 2006-2009 \\
\hline
\end{tabular}

Table 3. Venues for the World Congress of Psychiatric Genetics (WCPG) sponsored by ISPG and corresponding Chairs/Co-Chairs.

\begin{tabular}{|l|}
\hline 1993: New Orleans (Theodore Reich ${ }^{*}$ ) \\
\hline 1995: Cardiff (Peter McGuffin/Michael Owen) \\
\hline 1996: Interim San Francisco (Lynn DeLisi) \\
\hline 1997: Santa Fe (Lynn DeLisi) \\
\hline 1998: Bonn (Propping */Markus Nöethen) \\
\hline 1999: Monterey (John Nurnberger, Jr) \\
\hline 2000: Versailles (Jacques Mallet) \\
\hline 2001: St. Louis (Richard Todd) \\
\hline 2002: Brusselles (Christine Van Broeckhoven) \\
\hline
\end{tabular}


Table 3. Cont.

\begin{tabular}{|l|}
\hline 2003: Quebec City (Nicholas Barden) \\
\hline 2004: Dublin (Michael Gill) \\
\hline 2005: Boston (Stephen Faraone) \\
\hline 2006: Sardinia (Maria Del Zompo) \\
\hline 2007 New York City (Lynn DeLisi/Douglas Levinson) \\
\hline 2008: Osaka (Hiroshi Yoneda) \\
\hline 2009: San Diego (John Kelsoe/Martin Schalling) \\
\hline 2010: Athens (Nicholas Craddock/George Papadimitriou) \\
\hline 2011: Washington D.C. (Francis McMahon/Thomas Schulze) \\
\hline 2012: Hamburg, Germany (Markus Nöethen/Marcella Rietschel) \\
\hline 2013: Boston, MA (Jordan Smoller/Lynn DeLisi) \\
\hline 2014: Copenhagen, Denmark (Thomas Schulze, Oli Mors) \\
\hline 2015: Toronto, Canada (James Kennedy) \\
\hline 2016: Jerusalem, Israel (Bernard Lerer, Elliot Gershon) \\
\hline 2017: Orlando, Florida (Stephen Faraone, Daniel Rujescu) \\
\hline $\begin{array}{l}\text { 2018: Glasgow, Scotland (Mandy Johnstone, Benjamin Pickard, } \\
\text { Jonathan Sebat) }\end{array}$ \\
\hline 2019: Anaheim, California, (Daniel Geschwind, John Kelsoe) \\
\hline
\end{tabular}

* deceased.

Table 4. Awards presented by ISPG.

\begin{tabular}{|l|}
\hline Lifetime Achievement Awardees \\
\hline 1993: Seymour S. Kety * and George Winokur * \\
\hline 1995: Ming T. Tsuang \\
\hline 1997: Irving I. Gottesman * \\
\hline 1999: Theodore Reich * \\
\hline 2001: P. Michael Conneally * \\
\hline 2002: Jules Angst and Nikki Erlenmeyer-Kimling \\
\hline 2003: C. Robert Cloninger \\
\hline 2004: Peter Propping * \\
\hline 2005: NONE \\
\hline 2006: Elliot S. Gershon \\
\hline 2007: Peter McGuffin \\
\hline 2008: Jurg Ott \\
\hline 2010: Susan E. Folstein \\
\hline 2011: Kenneth S. Kendler \\
\hline 2012: Raymond Crowe \\
\hline 2013: John I. Nurnberger, Jr \\
\hline 2014: Margaret Pericak-Vance \\
\hline 2015: Michael Owen \\
\hline 2016: Raymond DePaulo, Jr. \\
\hline 2017: Pamela Sklar * and Marcella Rietschel \\
\hline 2018: Stephen Faraone \\
\hline
\end{tabular}


Table 4. Cont.

\begin{tabular}{|l|}
\hline Reich Junior Investigator Award (Began in 2004) \\
\hline 2004: Carol Prescott \\
\hline 2005: Laura Almasy and Nigel Williams \\
\hline 2006: Thomas G. Schulze \\
\hline 2007: Alexander B. Niculescu III \\
\hline 2008: Shaun Purcell \\
\hline 2009: Jonathan Sebat \\
\hline 2010: Elisabeth B. Binder \\
\hline 2011: David Glahn \\
\hline 2012: Danielle Dick \\
\hline 2013: Stephan Ripke \\
\hline 2014: Benjamin Neale \\
\hline 2015: Sarah Medland \\
\hline 2016: Menachem Fromer \\
\hline 2017: Jonathan Mill \\
\hline 2018: Arpana Agrawal \\
\hline Richard Todd Child Psychiatric Genetics Award (began in 2009) \\
\hline 2009: Robert Althoff \\
\hline 2010: Joseph D. Buxbaum \\
\hline 2011: Danielle Dick \\
\hline 2012: Anke Hinney \\
\hline 2013: Geert Poelmans \\
\hline 2014: Nadine Provencal \\
\hline 2015: Christie Burton \\
\hline 2016: Joseph Buxbaum \\
\hline 2017: Danielle Posthuma \\
\hline 2018: F. Kyle Satterstrom \\
\hline Gershon Paper of the Year Award \\
\hline 2014: Thomas W. Muhleisen \\
\hline 2015: Michael O’Donovan and Stephen Ripke \\
\hline 2016: Liping Hou, Urs Heilbronner and Franziska Degenhardt \\
\hline 2017: Chi-Hua Chen \\
\hline 2018: Verneri Anttila \\
* deceased. \\
\hline
\end{tabular}

The ISPG and WCPG continue to be successful for years to come recording progress toward understanding the genetics in a wide range of psychiatric disorders and how to apply research results to better the care of people at risk for or having psychiatric disorders.

\section{CONFLICTS OF INTEREST}

The author declares that she has no conflicts of interest. 


\section{REFERENCES}

1. Mendel G. EXPERIMENTS IN PLANT HYBRIDIZATION (1865). Available from http://www.esp.org/foundations/genetics/classical/gm-65.pdf. Accessed 2019 Oct 8.

2. Mendel G. Versuche über Pflanzen-Hybriden. Verh. naturf. Ver. Brünn. 1866;4:3-47. German.

3. Bateson W, Sanders ER, Punnett RC. Experimental studies in the physiology of heredity. Reports to the Evolution Committee of the Royal Society, Report II. London (UK): Harrison and Sons; 1905. p. 1-99.

4. Johannsen W. Elemente der exakten Erblichkeitslehre. Cambridge (UK): Cambridge University Press; 1909. German.

5. Rieder RO, Gershon ES. Genetic strategies in biological psychiatry. Arch Gen Psychiatry. 1978;35:866-73.

6. Weissman MM, Gershon ES, Kidd KK, Prusoff BA, Leckman JF, Dibble E, et al. Psychiatric disorders in the relatives of probands with affective disorders. The Yale University--National Institute of Mental Health Collaborative Study. Arch Gen Psychiatry. 1984;41(1):13-21.

7. Gusella J, Wexler N, Conneally P, Naylor SL, Anderson MA, Tanzi RE, et al. A polymorphic DNA marker genetically linked to Huntington's disease. Nature. 1983;306:234-8.

8. Detera-Wadleigh SD, Miguel C, Berrentini WH, DeLisi LE, Goldin LR, Gershon ES. Neuropeptide gene polymorphisms in affective disorder and schizophrenia. J Psychiatr Res. 1987;21(4):581-7.

9. DeLisi LE, Wise CD, Bridge TP, Wagner R, Karson C, Potkin SG, et al. A probable neuroleptic effect on platelet monoamine oxidase activity. Psychiatry Res. 1981;4(1):95-107.

10. DeLisi LE, Goldin LR, Maxwell ME, Mueller DB, Gershon ES. A clinical study of siblings with schizophrenia. Arch Gen Psychiatry. 1987;44:891-6.

11. Detera-Wadleigh SD, Miguel C, Berrentini WH, DeLisi LE, Goldin LR, Gershon ES. Neuropeptide gene polymorphisms in affective disorder and schizophrenia. J Psychiatr Res. 1987;21(4):581-7.

12. Goldin LR, DeLisi LE, Gershon ES. HLA antigens and schizophrenia. Psychiatry Res. 1987;20:69-77.

13. Gershon ES, DeLisi LE, Maxwell E, Hamovit J, Guroff J. A controlled family study of chronic psychoses. Schizophrenia and Schizoaffective disorder. Arch Gen Psychiatry. 1988;45:328-36.

14. Alkelai A, Baum A, Carless M, Crowley J, Dasbanerjee T, Dempster E, et al. The XVth World Congress of Psychiatric Genetics, October 7-11, 2007: Rapporteur summaries of oral presentations. Am J Med Genet B Neuropsychiatr Genet. 2008;147B(2):233-77.

15. Anderson-Schmidt H, Beltcheva O, Brandon MD, Byrne EM, Diehl EJ, Duncan $\mathrm{L}$, et al. Selected rapporteur summaries from the XX World Congress of Psychiatric Genetics, Hamburg, Germany, October 14-18, 2012. Am J Med Genet B Neuropsychiatr Genet. 2013;162B(2):96-121. doi: 10.1002/ajmg.b.32132 
16. Akpudo H, Aleksic B, Alkelai A, Burton C, Carillo Roa T, Chen DT, et al. Summaries of oral sessions at the XXI World Congress of Psychiatric Genetics, Boston, Massachusetts, 17-21 October 2013: state of the field. Psychiatr Genet. 2014;24(4):125-50. doi: 10.1097/YPG.0000000000000043

How to cite this article:

DeLisi LE. An Historical Perspective on Psychiatric Genetics, the International Society of Psychiatric Genetics and the Role of Elliot Gershon. J Psychiatry Brain Sci. 2019;4:e190015. https://doi.org/10.20900/jpbs.20190015 